\title{
Gender matters: Family background and upper secondary education in Finland
}

\begin{abstract}
The intergenerational transmission of education and social position is a widely studied topic, but measurement of the significance of gender in this subject has reached less attention. We study gender differences in the effect of parental disadvantage on the probability of a child completing upper secondary education in Finland. We use high-quality register data, collected by Statistics Finland. The data are clustered according to families that includes information on both children and their parents. The data consist of a 25 percent sample of persons born in Finland between 1980 and 1986 ( $\mathrm{n}=157$ 135). The data are analysed using sibling methods using random-effects linear probability models. The analyses are run separately for daughters and sons. With the exception of parental unemployment, all the indicators measuring disadvantaged parental background are significantly more strongly connected to the probability of sons than the probability of daughters completing upper secondary education. Father's unemployment is a stronger predictor of the child's probability of completing upper secondary education than unemployment of the mother. The mother's educational level predicts a child's probability of completing upper secondary education more strongly than the educational level of the father. Both mothers' and fathers' educational levels have a significantly stronger correlation with sons' than daughters' completion of upper secondary education. Equality of opportunity seems to be achieved better among girls than among boys. It might be the case, that the educational system as one of the most important paths for achieving superior social status to one's parents, does not treat girls and boys equally. It would be especially important to pay more attention to boys' school readiness and school wellbeing especially in socioeconomically disadvantageous areas.
\end{abstract}

KEYWORDS: Disadvantage, intergenerational transmission, gender, secondary education 


\section{Introduction}

Despite the comprehensive welfare state, social position is also inherited in Finland, especially at the bottom of the social pyramid (Sirniö 2016). Socio-economic position is largely inherited through educational attainment (Breen \& Karlson 2013). In Finland completion of upper secondary education is especially important as it is a precondition for higher levels of education and increasingly important for accessing the labour market. Not completing upper secondary education increases the risk of many social problems later in life such as unemployment, poverty, early retirement and exclusion from society (Bäckman \& Nilson 2011). The effect of social origin on school choices is stronger the younger an individual is (Breen \& Jonsson 2000). Thus the family background more strongly determines the transition from compulsory school to secondary school than later educational transitions (Schneider 2008).

In Finland, upper secondary education has two tracks. After compulsory education of nine years, with no tracking, children completing compulsory education choose between general and vocational education. Both options typically take three years to complete and are free of charge. Most 16-year-olds continue in education, but there is a problem relating to the number of students dropping out at this level. Approximately 88 percent of young people complete upper secondary school by the age of 24 (Eurostat 2019).

In general, men lack upper secondary education more often than women. Concern about social exclusion also applies, especially for young men; of all young people at risk of social exclusion, two-thirds are estimated to be young men (Myrskylä 2012). Upward social mobility is perceived to be more common among women than among men, and it is likely that this difference can be explained by women's higher educational attainment (Erola \& Pöyliö 2015). According to the latest PISA results, the gap in performance between boys and girls is growing, and among the OECD countries, Finland has the largest gap.

The intergenerational transmission of education and social position is a widely studied topic, but measurement of the significance of gender in this subject has reached less attention. Also, there has been very little detailed investigation of gender differences in the significance of single forms of family resources or disadvantage factors on educational attainment. Earlier research has indicated that the educational level of mothers is more strongly connected to children's educational attainment than that of fathers (Korupp et al. 2002; Erola et al. 2016) but whether there is a difference in effect between sons and daughters is still unclear. While international research suggests that unemployment of fathers is more detrimental to children's educational outcomes (Kalil \& Ziol-Guest 2008; Rege et al. 2011) studies from Finland, where female labour market participation has been at a high level for a long time, are rare. It is also not clear whether the unemployment of mother or father affects sons' and daughters' educational attainment differently.

In this study we analyse gender differences in the association between parental disadvantage and the probability of a child successfully completing upper secondary school by the age of 22 . 
We further study how parental level of education is associated with the probability of sons and daughters completing upper secondary education. To fully understand the gender differences, we have measured unemployment and the educational level of mothers and fathers separately.

\section{The significance of family resources and gender}

Family background affects at each level of educational attainment, both through academic performance and through educational transitions. However, as girls and boys share the same household, what explains the differences in educational performance and outcomes? Do family resources have the same effect on sons and daughters and does this depend on the type of resource? Do maternal and paternal unemployment or educational level have a different effect on the educational attainment of sons and daughters?

\subsection{Parental poverty and gender}

The association between parental poverty and children's educational attainment has been reported in countless studies. A lack of economic resources creates obstacles that tend to lower educational attainment (Bäckman \& Nilsson 2011; Larsen et al. 2014). Children from poor families are found to have a lower probability of completing secondary education than children from non-poor families (Kallio et al. 2016).

Parental poverty prevents parents from offering children financial help during studies which is regarded as a form of encouragement to move into the labour market earlier. In Finland, exhaustion caused by trying to combine studies and paid labour is emphasized in reasons for ending up on disability pension especially among students from poor families (Rikala 2018). Perceived economic pressure can also cause parental stress, anxiety and depression, which can lead to tensions in parent-child interactions (Ridge 2011), deviant behaviour (Albrecht \& Albrecht 2011) and increased risk of mental health problems in adolescence (Paananen et al. 2012), which in turn are associated with school dropout. Children may also adopt the disadvantaged identity which may limit their visions and expectations for the future (Alanen et al. 2014).

Most of the existing literature suggests that boys are more vulnerable to the effects of economic scarcity on educational attainment (Entwisle et al. 2007; Chetty et al. 2016). Economic stress in family is found to have a stronger effect on academic readiness, academic skills and academic and behavioural problems and self-esteem among boys than girls (Obradović et al. 2010; Autor et al. 2019).

The stronger effect of poverty on boys than on girls has been explained by cultural issues. Gender contracts seem to emphasize work and earnings as being central to masculinity (e.g. Damantas \& Myers 2015). This applies also in Finland where the male breadwinner model has not in fact really existed for almost a century. In Finland, poor men have been found to experience more profound worthlessness than poor women. Men's role in the gender contract is seen as being tied to work, money and markets whereas women have more means of attaining a sense of worth outside the economic realm. (Isola et al. 2019.) Boys can adopt these norms already early on and the lack of economic resources can thus lead to stigmatization and self- 
esteem problems, which again can reflect on general wellbeing and school work. Economic scarcity in families can also cause more stress among fathers, which, based on the gender role hypothesis, can have a more negative impact on boys than girls.

Some other studies have, however, obtained different results, according to which contemporary young women's identities strongly include work and financial success (Danziger \& Ratner 2010) and that economic independence is a key marker of adulthood for both genders (Arnett 2004). Mixed results may be due to different ways of measuring stress as there are also many studies showing the effect of poverty on maternal mental health (e.g. Boyd-Swan et al. 2016; Fitzsimons et al. 2017).

\subsection{Receiving social assistance and gender}

Social assistance in Finland is a means-tested benefit that is intended to be a last resort and temporary support for individuals and families facing exceptional and unexpected economic hardship. The benefit has, nevertheless, become a permanent source of income for many families. Approximately 7 percent of the population of Finland received social assistance in 2015 (Tanhua \& Kiuru 2016). In addition to poverty and unemployment social assistance receipt is associated with accumulated social problems (Kuivalainen et al. 2013).

Parental social assistance receipt strongly reduced the likelihood of the children completing upper secondary education even after controlling for parental poverty, unemployment and educational level (Kallio ym. 2016). Social assistance receipt may affect the probability of completing upper secondary education in many ways. Accumulated problems in families can affect offspring through for example hereditary and prenatal factors and through the environment at home. Psychiatric illness is more common among social assistance recipients. Mental health problems can cause social isolation and undermine the way children are taken care both mentally and physically. (Ringbäck-Weitoft et al. 2008.) Also, upper secondary education is not necessary for status maintenance for children of families receiving social assistance (Becker \& Hecken 2009).

Boys whose parents have received social assistance are more likely than girls to receive it themselves in their adulthood (Moisio \& Kauppinen 2011, 13). As far as we know, gender differences in the effect of parental receipt of social assistance on educational attainment of children have not been studied in Finland. Ringbäck-Weitoft et al. (2008) found no gender differences in the association between the family receiving social assistance and children's health and social outcomes in Sweden.

\subsection{Parental unemployment and gender}

Parental unemployment is found to be associated with children's literacy (Siddiqui et al. 2007), school grades (Rege et al. 2011), grade repetition, school suspension (Stevens \& Schaller 2011), schooling ambitions and educational outcomes (Ström 2003; Müller 2017). In Finland, parents' long absences from the labour market are strong predictors of the NEET-typed trajectories of children (Ristikari et al. 2016). Kallio et al. (2016) found that parental unemployment diminish the probability of a child completing secondary education. 
In Finland, the state together with unemployment funds provides social security for the unemployed. The negative effects of unemployment go beyond economic resources. One of the heaviest burdens of job loss is losing community and social integration. An unemployed person is outside the social institution to which the majority of the working-age population belong. This may generate a culture of outsiders at home and affect future horizons negatively. (Järvinen 1999; Bäckman \& Nilsson 2011.) Both unemployed parents and their children are affected by psychological stress (Levine 2011), which may cause lower mental health (Ström 2003), tensions in family relationships (Coelli 2011) and compromised parenting practices (Euser et al. 2010). Parental unemployment is associated with the risk of troublesome behaviour and school suspension among children, which is associated with increased risk of school dropout (Harland et al. 2002; Skiba \& Peterson 2003).

Bratberg et al. (2008) report that in Norway the effect of paternal unemployment is greater on sons than on daughters. Mensah and Kiernan (2010) found the negative association between unemployment of parents and children's early learning to be more pronounced for boys and expected the effect to accumulate over time as the children grow and develop. Many studies indicate that unemployment causes higher psychological stress among fathers than among mothers and that fathers' unemployment is more detrimental to children's academic progress and educational outcomes (Hultman et al. 2006; Kalil \& Ziol-Guest 2008; Rege et al. 2011). Nevertheless, in a Finnish study, maternal unemployment had stronger association with disadvantageous trajectories for sons than paternal unemployment. Female labour market participation in Finland has been at a high level for a long time, so traditional roles may have weakened (Ristikari et al. 2016). Also Hérault and Kalb (2016) found that daughters' outcomes were only affected by maternal unemployment. Overall, results underline that gender differences exist in response to job loss and parental unemployment, but research on the topic is needed in more egalitarian societies, particularly since gender roles continue to shift.

\subsection{Parental educational level and gender}

Children of parents with an academic background attend university more often than children from working-class families (Kivinen \& Hedman 2016). Kallio et al. (2016) found that maternal tertiary education increases the probability of a child completing secondary education compared to a mother with compulsory education only. In many studies, parental educational level appears to be a significant factor in predicting children's educational level. That is why the tertiary education of parents might also compensate for the lack of other resources by protecting children against the effects of disadvantages (Levine 2011; Erola \& Kilpi-Jakonen 2017).

According to Bourdieu, parental education reflects the cultural capital of the family. Cultural capital comprises educational level, tastes, priorities and knowledge about the educational system. In the home environment children learn the normative codes that are rewarded by the teachers (Jaeger \& Holm 2007). Cultural capital increases the ability of educated parents to promote their children's educational success, which is why their children are more likely to do well at school (Buis 2013). Highly educated parents may also have more strategic knowledge about making educational choices (Kallio et al. 2016). 
In many studies, boys are found to be more vulnerable to the effects of low parental education and upward social mobility seems to be more common among women (OEDC 2015; Autor et al. 2019; Bukodi \& Paskov 2020). However, some previous research has established that the parental level of education has a stronger effect on the educational attainment of girls (Bäckman \& Nilson 2011). Minello and Blossfeld (2016) found no significant differences in the effect of maternal and paternal education on the educational attainment of sons and daughters with one exception: maternal tertiary education was a significantly stronger predictor of daughters obtaining higher education than was paternal tertiary education. In many studies, maternal level of education has proven to be a more significant factor than paternal educational level in predicting the educational outcomes of offspring (Erola et al. 2016). This result can be understood by the fact that mothers usually spend more time with their children, and therefore their cultural resources are more important.

\subsection{Other explanations for gender differences}

An interesting fact in gender differences in school performance and outcomes is that the gender gap widens as one moves down the social ladder (Entwisle et al.2007; Chetty et al.2016; Bukodi \& Paskov 2020). The widening gender gap in lower socioeconomic classes is thus likely to be explained by cultural, rather than economic factors (Mensah \& Kiernan 2010). One such cultural factor is traditional norms of masculinity. While the female role is more flexible, the male role has more clear standards for success, such as power, dominance, independency, competitiveness, activity and control. When a man experiences socioeconomic deprivation and is not able to improve his situation, he may experience a loss of control and helplessness detrimental to his masculine identity. Adolescent males often react to this with excessive masculinity which increases their vulnerability to risks of all kinds. (Möller-Leimkühler 2003.)

In schools, this kind of adverse masculinity takes the form of the development of an antilearning culture among boys who have problems achieving educational success (Connolly 2006; Bukodi \& Paskov 2020). Working-class fathers may unconsciously reinforce conception of school as a somewhat feminine field, because school was never a source of masculine power to them. The peer pressure to adopt masculine identities seems to be particularly strong for boys from working- or lower class families. (DiPrete \& Buchmann 2013.)

Schools are also regarded having become dominated by a feminine culture that does not support boys' way of behaving and learning (Entwisle et al.2007). Maybe partly due to this girls are perceived as showing greater levels of attachment to school than boys (DiPrete \& Buchmann 2013). Boys are also overrepresented in populations with antisocial behaviour, attention disorders, learning disabilities, mental developmental and behavioural problems (Moffitt et al. 2001) which also contribute to educational outcomes.

Taking all these socio-cultural dimensions into account, boys might need more parental support than girls to fare well in the educational system. DiPrete and Buchmann (2013) argue that highly educated fathers especially may have a central role in providing boys with a concrete role model for the type of masculine identity that includes educational achievement and makes it a masculine accomplishment. 
According to earlier research a disadvantaged family background seems to be associated with educational achievement through many mechanisms. Although we know a great deal about the significance of single disadvantage factors on children's educational attainment, gender differences in this context have received less attention, and even less in research considering more than one disadvantage factor simultaneously. Earlier research indicates that boys are in general more vulnerable to the negative effects of disadvantage, at least as for educational attainment but results are nevertheless inconsistent. It is also so far unclear how the significance of parent's gender appears in the Nordic context which may, internationally, have some very distinctive characteristics when it comes to the gender contract.

\section{Data and methods}

\subsection{Data}

Our register-based data is collected by Statistics Finland. The data includes 25 percent of people born between 1980 and 1986 and their biological siblings from the same time period. The sample persons and their siblings were clustered into families. One person in each family was randomly selected as the main sample person. Parental information was picked from the year the main sample person was 15 years old and was thus presumably making the transition from compulsory to secondary education. All sample persons not living with their biological or adoptive parents as well as those not living in Finland between the ages of 15 and 22, were removed from the data along with their siblings (9.8 percent of all sample persons). The data includes 157,135 children in 101,915 families. 19 percent of all the sample persons were living in single-parent households. Gender distribution is even, as 51 percent of the sample persons were men and 49 percent were women.

\subsection{Dependent variable}

As a dependent variable we use completion of either upper secondary general or vocational education by the age of 22. In the International Standard Classification of Education, lower secondary education in Finland is part of compulsory education; our dependent variable marks completion of the level after compulsory education. In our sample, 83 percent had completed secondary education by the age of 22 and 17 percent had not (see Table A). 87 percent of women and 80 percent of men had finished secondary education by the age of 22 .

[Table A here]

\subsection{Independent variables}

We measure parental poverty by relative income poverty (less than 60 percent of the median income of all parents). Because parents are in general poorer than non-parents, we acknowledge that the poverty line used here is probably slightly lower than the poverty line in the whole population. The indicator was formed by dividing the total of the parents' deflated 
income by the number of family members (equivalent income). The measure used is crude but a more rigorous measure was not available due to data limitations.

Receipt of social assistance was measured during the last 12 months with three-class variable indicating whether the family had received social assistance for 0 , for 1-5 or for more than 6 months. Parental unemployment was measured separately for mothers and fathers during the last 12 months. Parental education was measured using a four-category variable indicating the highest level of their mothers' and fathers' education (compulsory, upper secondary or tertiary). The data only includes parents living in the same household with the sample person, and due to the high number of single-parent families, there were many missing values for fathers' educational information. Missing values form the fourth category of educational level (unknown).

The control variables include possible immigrant background, number of children and single parenthood in the childhood family. The immigrant population has increased rapidly in Western Europe. It has been found that children, especially boys, from an immigrant background especially from less developed countries fare worse than average in the European educational system (Heath et al. 2008). Additionally, single parenthood has been found to have a negative effect on children's educational attainment (McLanahan \& Percheski 2008). All these factors may be considered to be possible complicating factors and are commonly controlled for in this type of research (Kallio et al. 2016).

\subsection{Methods}

In our analysis, we used a random-effects linear probability model. This method is intended to be used for multilevel data that include both individual and group level variables. In hierarchical data, the observations are dependent on each other, i.e. there is similarity between the individuals within groups. These data meet the conditions as the sample persons are clustered into families.

Compared to the individual level regression method, multilevel analysis produces more precise standard error terms and thus confidence intervals and significance test estimates. This is because with random effect multilevel models it is possible to take into account the sibling similarity caused by the same family background. Multilevel analysis makes it possible to estimate Intra Class Correlation (ICC), which in our case refers to the amount of resemblance between siblings in their probability of completing secondary education. Further, it is possible to compare the variance within families (i.e. between siblings) to variance between families (i.e. variance in means of sibling clusters). When Intra Class Correlation is used in calculating the variance between siblings, the method is sometimes called sibling correlations (see Conley 2008).

More variance within than between families would indicate that individual-level factors are a stronger predictor of completing secondary education than family-level factors. In this kind of situation sibling correlation (ICC) would be lower. Instead, less variance within families than between families would indicate the power of family-level factors in predicting completion of secondary education. Sibling correlation is sometimes regarded as an omnibus for all the 
otherwise unobserved family background-related factors and is used to tackle the problem of underestimating the total effect of family background (Sieben \& De Graaf 2013, 441).

Our analysis strategy was as follows: after estimating an empty model, we introduced the disadvantage variables into the following models one by one (see models 1-4). In the fifth model we added all the disadvantage factors into the analysis simultaneously, i.e., controlled them with each other. In the last two models (6-7) we introduced the mother's and father's educational level into the analysis. The control variables were included throughout the analysis. Finally, we tested interaction effects between all the independent variables and gender separately (figures not reported her but available if needed).

\section{Results}

According to the descriptive results (not reported here), daughters completed upper secondary education more often than sons in every family characteristic group. The gender-based gap was widest among children whose parents had received long-term social assistance and the smallest between sons and daughters of highly educated parents.

Model 1 in the random-effects linear probability models (see Tables B and C) shows that parental poverty was negatively associated with the educational level attained by both sons and daughters. Daughters of poor parents had 8 percentage points and sons 9 percentage points lower probability of completing upper secondary school compared with children whose parents were not poor. There was an interaction effect between gender and poverty, and poverty was significantly more strongly associated with the educational attainment of sons than that of daughters.

Of all the examined factors, parental receipt of social assistance had the strongest association with completing secondary education for both sons and daughters (see model 2). Compared to the reference group, women whose parents received short-term social assistance (from 1-5 months) were 14.2 percentage points less likely to complete secondary education, while men with the same characteristics were 15.2 percentage points less likely. Daughters of parents who received social assistance long term (6 months or more) completed secondary education 22.1 and sons 23.7 percentage points less often than sample persons in the reference group. Gender differences were significant, as there was an interaction effect between gender and parental receipt of both short- and long-term social assistance.

Maternal unemployment had a significant negative association with completing secondary education for both sexes, more so for daughters than sons. Model 3 shows that maternal unemployment reduced the probability of completing secondary education by 6.7 percentage points among daughters and 6.4 percentage points among sons compared to children whose mothers were not unemployed. Paternal unemployment reduced the probability of completing secondary education even more. Compared to the reference category, women whose fathers had experienced unemployment were 7.4 percentage points less likely to complete secondary education, while men were 8.2 percentage points less likely (see Model 4). Nevertheless, the gender difference in the association of maternal or paternal unemployment on completing 
secondary education was not significant, i.e., there was no interaction effect between gender and maternal or paternal unemployment.

[Table B here]

Model 5 suggests that parental poverty, receipt of social assistance and both maternal and paternal unemployment independently affect the likelihood of children completing secondary education for both daughters and sons. Maternal unemployment continues to have a stronger correlation with daughters' completing secondary education. All the estimates decreased, but the smallest decrease was observed for the association of parental receipt of social assistance.

\section{[Table Chere]}

In the sixth model, the maternal educational level was examined. The maternal level of education significantly correlated with completing secondary education for both daughters and sons. Compared to the reference group, mothers' secondary education increased the probability of completing secondary education by 7.2 percentage points for daughters and 8.3 percentage points for sons. The tertiary education of the mother increased the probability of completing secondary education by 12.1 percentage points for daughters and 16 percentage points for sons. Gender and maternal level of education interacted - maternal level of education was a significantly stronger predictor of sons' educational attainment than of daughters' educational attainment.

In the last model, fathers' educational level was introduced into the model (see model 7). Paternal educational level also correlated significantly with the probability of completing secondary education for both daughters and sons. Women whose fathers had completed secondary education were 3.7 percentage points more likely to complete secondary education, while men were 5.1 percentage points more likely. Fathers' tertiary education increased the probability of completing secondary education by 8.6 percentage points among daughters and by 12.3 percentage points among sons. There was an interaction effect between gender and fathers' educational level, as fathers' level of education had a significantly stronger correlation with completing secondary education for sons than daughters.

Finally, we concentrate on the sibling correlations (ICC) in every category of parental disadvantage (see Tables B and C). The level of ICC was very similar in models 1, 3 and 4 in which the association of poverty and maternal and paternal unemployment was considered. In the second model, where the association of parental receipt of social assistance was examined, the ICC became significantly smaller, which indicates that family background plays a larger role for children who grow up in families receiving social assistance. The ICC was even smaller when maternal education was introduced into the model (see model 5). The effect on ICC of adding fathers' educational level to the model was less pronounced. Because there were no massive changes in the family variance estimate after adding disadvantage factors into the model, it 
seems that there are other family background-related factors that explain differences between families apart from the factors used here as independent variables.

\section{Conclusions}

In general level results confirmed the earlier knowledge about the association between parental background and educational attainment. The strongest association of parental receipt of social assistance was also expected and supports the assumption of cumulative disadvantages among social assistance recipients that is not captured by economic measured alone. The order of the different aspects of disadvantage in their relative effect on secondary education completion was similar among girls and boys.

Among both sons and daughters, paternal unemployment seemed to predict completing secondary education more strongly than maternal unemployment. This is a somewhat surprising finding as according to the earlier results from Finland (Ristikari et al. 2016) maternal unemployment was more detrimental for children's outcomes. On the other hand, in a recent qualitative study Isola et al. (2019) found that men's role in the gender contract is still stronger tied to the economic realm, including work. Unemployment of the father can thus cause more familial stress, which negatively impacts on children.

Maternal educational level predicted children's probability of completing secondary education more strongly than paternal educational level. The result is consistent with earlier studies indicating that the mothers' level of education predicts children's educational attainment more strongly than the fathers' level of education (Korupp et al. 2002; Erola et al. 2016). Maternal educational level is believed to have a stronger association because mothers in general spend more time with their children than fathers (e.g. Magnusson et al. 2009; Buis 2013). If this is the underlying mechanism, then it can be assumed that the difference between the association of mothers' and fathers' educational level on the educational level of children will be smaller in countries such as the Nordics, where the caring of children is more evenly distributed between parents (e.g. Craig \& Mullan 2011). It is also possible that mothers being role models is emphasized in countries where their labour market participation is high. Among OECD countries, on the other hand, high education of the father is found to have the strongest association with sons' high educational attainment in Finland (Esping-Andersen \& Wagner 2012). This inconsistency indicates that mothers' and fathers' educational levels may operate differently in different educational transitions.

Sons seem to be more vulnerable to the effects of disadvantaged parental background. Excluding both maternal and paternal unemployment, all the indicators were stronger predictors of completing secondary education for sons than daughters. Parental poverty exhibited a significantly stronger association to the educational attainment of sons than of daughters. This result supports previous studies on the topic, which are rare but quite consistent - economic hardship has systematically proven to be a more significant disadvantage for the success of boys than that of girls (Entwisle et al. 2007; Chetty et al. 2016). 
An explanation for this result may be found in cultural factors; perhaps the importance of money and economic wellbeing are more emphasized among men than among women. There is some evidence of strong male-breadwinner assumptions even in western culture (Kalil \& Ziol-Guest 2008, 512; Isola et al. 2019), and boys can adopt these norms at a very young age. Lack of economic resources may cause stronger stigma for boys, while girls confront different types of demands. Economic hardship in a family may also be a particularly large stress factor for fathers, and according to the sex-role hypothesis, this can have a greater impact on sons than on daughters. On the other hand, there are also many studies showing the effect of poverty on maternal mental health (e.g. Boyd-Swan et al. 2016; Fitzsimons et al. 2017).

Additionally, parental receipt of social assistance is a stronger predictor of completing secondary education for sons than for daughters. Receiving social assistance is related to a wide range of disadvantages. According to earlier studies, children who grow up in households receiving social assistance are more likely than others to receive social assistance in later life (Kauppinen et al. 2014), and this correlation is stronger for men than for women (Moisio \& Kauppinen 2011). Gender-related stereotypes and adverse masculinity ideals have also been observed to be strongest in the lowest social class, and it has been speculated that school may be regarded as a feminine field in these groups (Entwisle et al. 2007; Möller-Leimkühler 2003). Attitudes may be passed from parents to children either by intentional communication or unintentionally by the fathers' example.

In this study, both maternal and paternal unemployment were the only examined factors for which the association with completing secondary education was not significantly stronger for sons than for daughters. This result was surprising, as earlier studies have suggested that unemployment is a heavier burden for men than for women (Kalil \& Ziol-Guest 2008; Rege et al. 2011). Women are found to have other goals apart from that of family breadwinner and career growth, and concentrating on home making is perhaps less stigmatizing for women than it is for men. In addition, women often form their social networks through family and children and thus the social relationships formed through work are perhaps less important. One could therefore assume that the consequences of parental unemployment would reflect less on girls than on boys. According to this study this is not the case in Finnish context, which contradicts with our earlier result and interpretation about paternal unemployment having stronger association with children completing secondary education than maternal unemployment.

In addition, the educational level of both mothers and fathers predicted completing secondary school significantly stronger for sons than daughters. This result was consistent with earlier findings indicating that upward social mobility is higher among women than among men (Erola \& Pöyliö 2015). Results are similar to results from other Nordic countries (Bingley et al. 2009; Ermicsh \& Pronzato 2010). Finland may stand out in this respect as the gender gap in school performance is found to be widest among OECD countries and especially among socioeconomically disadvantaged children (Vettenranta et al. 2016).

The results of this study confirm the earlier understanding, that the aim of equality of opportunity is not achieved even in the Nordics and even less among males than females. Among lower socioeconomic classes, gender appears to be one of multiple factors exposing 
individuals to intergenerational inequality and disadvantaged positions. In Finnish society, the education system has been the primary means of increasing social mobility. It is possible that education, as the most important way of achieving a better social position than one's parents, may treat boys and girls unequally. Because of the notion that puberty in boys usually occurs at the most crucial period in which the most important educational choices are made, the Finnish government is also aiming at raising the age limit of compulsory education. To improve equality of opportunity, it would also be beneficial to dedicate more teachers and resources to schools in low socioeconomic areas.

The notion of a stronger connection between family background and completing secondary education for men than for women brings to light many questions in need of further investigation. Further work needs to be done to establish whether gender differences arise from actual differences in the way boys and girls experience disadvantages or whether differences follow from an unequal educational system or other environmental expectations. It would also be important to determine whether gender differences in background effects remain when moving from the secondary level to the tertiary level and whether there are some indicators of disadvantaged background that would correlate more strongly with the educational attainment of daughters. Would, for example, indicators of psychosocial disadvantage in a family more strongly predict the educational attainment of daughters than of sons? By differentiating socio-economic and psychosocial disadvantages, it would be possible to investigate their relationship, whether they have a protective effect on each other and whether the effect is different for sons and daughters. Protective and contributing factors may be differently emphasized for boys and girls.

\section{Funding}

This work was supported by The University of Turku Graduate School (UTUGS) and the Flagship Project of the Finnish Academy, Inequalities, Interventions and New Welfare State (INVEST) [grant number: 320162].

\section{Conflicts of interests}

The Authors declare that there is no conflict of interest.

\section{Acknowledgements}

The Authors want to acknowledge Timo Kauppinen for gathering the data and Hannu Lehti for assistance with the methods.

\section{References}

Alanen, O., Kainulainen, S. \& Saari, J: (2014) Vamos tekee vaikutuksen. Vamos-nuorten hyvinvointikokemukset ja tulevaisuuden odotukset. Helsinki: Helsingin Diakonissalaitos.

Albrecht, C. \& Albrecht, D. (2011) Social status, adolescent behavior, and educational attainment. Sociological Spectrum, 31, 114-137.

Arnett J. (2004) Emerging Adulthood: The Winding Road from the Late Teens through the Twenties. New York: Oxford University Press.

Autor, D., Figlio, D., Karbownik, K., Roth, J., \& Wasserman, M. (2019). Family disadvantage and the gender gap in behavioral and educational outcomes. American Economic Journal: Applied Economics, 11(3): 338-381. https:/ / doi.org/ 10.1257/ app.20170571

Becker, R. \& Hecken, A. (2009) Why are working-class children diverted from universities? An empirical assessment of the diversion thesis. European Sociological Review, 25, 233-250. 
Bingley, P., Christensen, K., \& Jensen, V. M. (2009). Parental schooling and child development: Learning from twin parents. Copenhagen, Denmark: Danish National Centre for Social Research.

Bolger, K., Patterson, C. \& Thompson, W. (1995) Psychosocial adjustment among children experiencing persistent and intermittent family economic hardship. Child Development, 66:4, 1107-1129.

Boyd-Swan, C., Herbst, C. M., Ifcher, J., \& Zarghamee, H. (2016) The Earned Income Tax Credit, Mental Health, and Happiness. Journal of economic behavior and organization, 126, 18-38.

Bratberg, E., Nilsen, A., \& Vaage, K. (2008) Job losses and child outcomes. Labour Economics, 15, 591-603.

Breen R. \& Jonsson J. O. (2000) Analyzing educational careers: a multinomial transition model. American Sociological Review 65:754-72.

Breen, R. \& Karlson, B. (2013) Education and Social Mobility. New Analytical Approaches. European Sociological Review, 30:1, 107-118.

Buis, M. (2013) The Composition of Family Backround: The Influence of the Economic and Cultural Resources of Both Parents on the Offspring's Educational Attainment in the Neatherlands between 1939 and 1991. European Sociological Review, 29:3, 593-602.

Bäckman, O. \& Nilsson, A. (2011) Pathways to social exclusion-A life-course study. European Sociological Review, 27:1,107-123.

Chetty, R., Hendren, N., Lin, F., Majerovitz, J., Scuderi, B. (2016) Childhood environment and gender gaps in adulthood. American Economic Review, 106, 282-8.

Coelli, M. (2011) Parental job loss and the education enrollment of youth. Labour Economics, 18:1, 25-35.

Conley, D. (2008). Bringing sibling differences in: enlarging our understanding of the transmission of advantage in families. In: Lareau A. and Conley D. (Eds.), Social Class: How Does It Work? New York: Russell Sage Foundation, pp. 179-200.

Connolly, P. (2006) The effects of social class and ethnicity on gender differences in GCSE attainment: a secondary analysis of the Youth Cohort Study of England and Wales 1997-2001. British Educational Research Journal, 32(1): 3-21.

Craig, L. \& Mullan, K. (2011) How Mothers and Fathers Share Childcare: A Cross-National Time-Use Comparison. American Sociological Review 76(6) 834-861.

Damantas I., Myers K. (2015) 'Step Up and Be a Man in a Different Manner': Unemployed Men Reframing Masculinity. The Sociological Quarterly, 56:640-64.

Danziger, S. \& Ratner, D. (2010) Labor Market Outcomes and the Transition to Adulthood. The Future of Children: Transition to Adulthood, 20:133-58.

Davis, B. (2003) Frogs and Snails and Feminist Tales: Preschool Children and Gender, rev. ed. New York: Hampton press.

Deslandes, R., Bouchard, P. \& St Amant, J. C. (1998) Family variables as predictors of school achievement: sex differences in Quebec adolescents. Canadian Journal of Education, 23(4): 390-404.

DiPrete, T. \& Buchmann, C. (2013) The Rise of Women: The Growing Gender Gap in Education and What it Means for American Schools, Russell Sage Foundation, New York.

Entwisle, D., Alexander, K. \& Olson, L. (2007) Early Schooling: The Handicap of Being Poor and Male. Sociology of Education, 80:2, 114-138.

Ermisch, J. \& Pronzato, C. (2010) Causal Effects of Parents' Education on Children's Education. ISER Working Paper Series No. 16.

Erola, J \& Kilpi-Jakonen, E. (2017) Social Inequality Across the Generations. The Role of Compensation and Multiplication in Resource Accumulation. Cheltenham: Edward Elgar Publishing.

Erola, J. \& Pöyliö, H. (2015) Suomen lisääntynyt sosiaalinen liikkuvuus harvinaista muualla Euroopassa. Talous ja Yhteiskunta, 4/ 2015.

Erola, J., Jalonen, S. \& Lehti, H. (2016) Parental education, class and income over early life course and children's achievement. Research on Social Stratification and Mobility, 44, 33-43.

Esping-Andersen, G. \& Wagner, S. (2012) Asymmetries in the Opportunity Structure. Intergenerational Mobility Trends in Europe. Research in Social Stratification and Mobility, 30:4, 473-487.

Eurostat (2019). Persons of the age 20 to 24 having completed at least upper secondary education by sex. available from: <http:/ epp.eurostat.ec.europa.eu/ portal/ page/ portal/ eurostat/ home>.

Fitzsimons, E., Goodman, A., Kelly, E. and Smith, J.P. (2017) Poverty dynamics and parental mental health: Determinants of childhood mental health in the UK. Social Science \& Medicine, 175, pp.43-51.

Harland, P., Reijneveld, S., Brugman, E., Verloove-Vanhorick, S., \& Werhulst, F. (2002) Family factors and life events as risk factors for behavioural and emotional problems in children. European Child \& Adolescent Psychiatry, 11, 176-184.

Heath, A., Rothon, C., \& Kilpi, E. (2008) The second generation in Western Europe: Education, unemployment, and occupational attainment. Annual Review of Sociology, 34, 211-235. 
Hérault, P. \& Kalb, G. (2016) Intergenerational correlation of labour market outcomes. Review of Economics of the Household, 14, 231-49.

Hultman, B., Hemlin, S. \& Hornquist, J. O. (2006) Quality of life among unemployed and employed people in northern Sweden. Are there any differences? Work, 26, 47-56.

Isola, A-M., Siukola, R. \& Kukkonen, M. (2019) Gendered Experiences of Poverty and Recognition in the Finnish Welfare State, NORA - Nordic Journal of Feminist and Gender Research, 27:3, 152-165

Jaeger, M. \& Holm, A. (2007) Does parents`economic, cultural and social capital explain the social class effect on educational attainment in the Scandinavian mobility regime? Social Science Research 36:2, 719-744.

Järvinen, T. (1999) Koulutuksen ja työelämän ulkopuolella. Teoksessa Kuorelahti \& Viitanen (toim.) Holtittomasta hortoilusta hallittuun harhailuun. Nuorten syrjäytymisen riskit ja selviytymiskeinot, 189-196. Helsinki: Mannerheimin Lastensuojeluliitto, Nuorisoasiain neuvottelukunta.

Kalil, A. \& Ziol-Guest, K. (2008) Parental employment circumstances and children's academic progress. Social Science Research, 37:2, 500-515.

Kallio, J., Kauppinen, T. \& Erola, J. (2016) Cumulative socioeconomic disadvantage and secondary education in Finland. European Sociological Review 32:5, 649-661.

Kauppinen, T., Angelin, A., Lorentzen, T., Bäckman, O., Salonen, T. \& Dahl, E. (2014) Social background and lifecourse risks as determinants of social assistance receipt among young adults in Sweden, Norway and Finland. Journal of European Social Policy 24:3, 273-288.

Kivinen, O. \& Hedman, J. (2016) Suomalaisen korkeakoulutuksen kansainvälinen taso on väitettyä parempi. Mahdollisuuksien tasa-arvo ja korkea osaaminen. Yhteiskuntapolitiikka 81:1.

Kuivalainen S., Hannikainen-Ingman, K. \& Sallila, S. (2013) Toimeentulotuen asiakkaiden elinolot ja hyvinvointi. Teoksessa Kuivalainen S. (toim.) Toimeentulotuki 2010-luvulla. Tutkimus toimeentulotuen asiakkuudesta ja myöntämiskäytännöistä. Terveyden ja hyvinvoinnin laitos, Helsinki.

Korupp, S. E., Ganzeboom, H. B. G. \& Van Der Lippe, T. (2002) Do Mothers matter? A comparison of models of the influence of mothers` and fathers` educational and occupational status on children`s educational attainment. Quality \& Quantity, 36:1,17-42.

Levine, P. (2011) How does parental unemployment affect children's educational performance? In G. Duncan \& R. Murnane (Eds.), Whiter opportunity: rising inequality, schools, and children's life chances (pp. 315-358). New York: Russell Sage Foundation.

Maccoby, E. (2003) The Two Sexes: Growing Up Apart, Coming Together. Cambridge, Mass.: Belknap press of Harvard University Press.

Magnuson, K., Sexton, H. R., Davis-Kean, P. E., \& Huston, A. C. (2009). Increases in maternal education and young children's language skills. Merrill-Palmer Quarterly, 55, 319-350.

McLanahan, S. \& Percheski, C. (2008) Family structure and the reproduction of inequalities. Annual Review of Sociology, 34, 257-276.

Mensah, F. \& Kiernan, K. (2010) Gender differences in educational attainment: Influences of the family environment. British Educational Research Journal, 36, 239-260.

Minello, A. \& Blossfeld, H-P. (2016) From parents to children: The impact of mothers` and fathers 'educational attainments on those of their sons and daughters in West Germany. British Journal of Sociology of Education, 38:5, 686-704.

Moffitt, T., Caspi, A., Rutter, M. \& Silva, P. (2001) Sex Differences in Antisocial Behavior: Conduct Disorder,

Moisio P. \& Kauppinen T. (2011) The intergenerational correlation of social assistance and selection bias in the Finnish Population. Research on Finnish Society, 4, 7-15.

Myrskylä, P. (2012) Hukassa - Keitä ovat syrjäytyneet nuoret? Elinkeinoelämän valtuuskunnan analyysi, 19:2.

Möller-Leimkühler, A. M. (2003) The gender gap in suicide and premature death: why are men so vulnerable? European Archives of Psychiatry and Clinical Neuroscience, 253(1): 1-8.

Obradović, J., Bush, N. R., Stamperdahl, J., Adler, N. E., \& Boyce, W. T. (2010) Biological sensitivity to context: The interactive effects of stress reactivity and family adversity on socioemotional behavior and school readiness. Child Development, 81 (1), 270-289.

OECD (2015) The ABC of Gender Equality in Education: Aptitude, Behaviour, Confidence, PISA, OECD Publishing.

Paananen, R., Ristikari, T., Merikukka, M., Rämö, A. \& Gissler, M. (2012) Lasten ja nuorten hyvinvointi. Kansallinen syntymäkohortti 1987 -tutkimusaineiston valossa. Raportti 52/ 2012. Helsinki: Terveyden ja hyvinvoinnin laitos.

Rege, M., Telle, K., \& Votruba, M. (2011). Parental job loss and children's school performance. The Review of Economic Studies, 78, 1462-1489.

Ridge, T. (2011) The everyday costs of poverty in childhood. A review of qualitative research exploring the lives and experiences of low-income children in the UK. Children \& Society, 25:1, 73-84.

Rikala, S. (2018) Masennus, työkyvyttömyys ja sosiaalinen eriarvoisuus nuorten aikuisten elämänkuluissa. Yhteiskuntapolitiikka 83:2. 
Ringbäck-Weitoft, G., Hjerna, A., Batljanc, I. \& Vinnerljunga, B. (2008) Health and social outcomes among children in low-income families and families receiving social assistance - A Swedish national cohort study. Social Science \& Medicine 66, 14-30.

Ristikari, T., Törmäkangas, L., Lappi, A., Haapakorva, P., Kiilakoski, T., Merikukka, M., Hautakoski, A., Pekkarinen, E. \& Gissler, M. (2016). Suomi nuorten kasvuympäristönä - 25 vuoden seuranta vuonna 1987 Suomessa syntyneistä nuorista aikuisista. Tampere, Finland: JuvenesPrint.

Schneider, T. (2008) Social inequality in educational participation in the German school system in a longitudinal perspective: pathways into and out of the most prestigious school track. European Sociological Review, 24,511-526.

Siddiqui, A., Subramanian, S., Berkman, L., Hertzman, C. \& Kawachi, I. (2007) The welfare state as a context for children's development: A study of the effects of unemployment and unemployment protection on reading literacy scores. International Journal of Social Welfare, 16, 314-325.

Sieben, I. \& De Graaf, P. (2013) Testing the Modernization Hypothesis and the Socialist Ideology Hypothesis: A Comparative Sibling Analysis of Educational Attainment and Occupational Status. The British Journal of Sociology 52:3, 441-467.

Sirniö, O. (2016) Constrained Life Chances. Intergenerational Transmission of Income in Finland. Department of Social Research, Faculty of Social Sciences, University of Helsinki.

Skiba, R. \& Peterson, R. (2003) Teaching the social curriculum: school discipline as instruction. Preventing School Failure 47:2, 66-73.

Stevens, A. \& Schaller, J. (2011) Short-run effects of parental job loss on children's academic achievement. Economics of Education Review, 30, 289-299.

Ström, S. (2003) Unemployment and families: A review of research. Social Service Review, 77(3), 399.

Tanhua, H. \& Kiuru, S. (2016) Toimeentulotuki 2015. Tilastoraportti 19/ 2016.

Vettenranta, J., Välijärvi,J., Ahonen, A., Hautamäki, J., Hiltunen, J., Leino, K., Läheinen S., Nissinen, K., Nissinen, V., Puhakka, E., Rautopuro, J. \& Vainikainen, M-P., (2016) PISA 15 Ensituloksia. Huipulla pudotuksesta huolimatta. Opetus- ja kulttuuriministeriön julkaisuja. 2016:41. 